\title{
KEDUDUKAN MAZHAB, TAKLID DAN IJTIHAD DALAM ISLAM
}

\author{
Muhammad Zuhdi Karimuddin \\ zukhdi@gmail.com \\ Dosen STIS Ummul Ayman Pidie Jaya
}

\begin{abstract}
Abstrabct. The Mazhab is interpreted as a way of thinking of a mujtahid in finding law from the original source, namely the Qur'an and Hadith, or the opinion of a mujtahid. The mazhab means to follow the opinion of Islamic jurists. The mazhab can also be interpreted as submitting to the Imam of the mazhab or religious followers of the mazhab of law. The mazhab or follow the mazhab as an alternative for those who are clouds or people who are unable to do ijtihad.
\end{abstract}

Keywords: Mazhab, Taklid and Ijtihad

Abtrak. Mazhab dimaknai sebagai jalan pikiran seorang mujtahid dalam menemukan hukum dari sumber aslinya, yakni Al-Qur'an dan hadis, atau pendapat seorang mujtahid. Bermazhab berarti mengikuti pendapat ahli hukum Islam. Bermazhab juga dapat diartikan sebagai bertaklid kepada Imam mazhab atau ulama pengikut mazhab dalam bidang hukum. Bermazhab atau mengikuti mazhab sebagai alternatif bagi orang awan atau orang yang tidak mampu berijtihad.

Kata Kunci: Mazhab, Taklid dan Ijtihad

\section{Pendahuluan}

Allah swt. mengharuskan umat mengikuti ajaran Al-Qur'an dan hadis. Meski Al-Qur'an sudah diturunkan secara sempurna dan lengkap, tidak berarti semua hal dalam kehidupan manusia diatur secara detail oleh Al-Qur'an maupun hadis. Selain itu ada perbedaan keadaan pada saat turunnya AlQur'an dengan kehidupan modern. Setiap sa

at masalah baru akan terus berkembang dan diperlukan aturan-aturan baru dalam melaksanakan ajaran Islam dalam kehidupan beragama sehari-hari. Syari'at Islam telah mengatur semua persoalan yang ada melalui Al-Qur'an dan hadis. Termasuk persoalan yang nawazil atau kontemporer. ${ }^{1}$

Tidak semua orang bisa memahami dalildalil, sebab manusia memiliki keterbatasan

1 Walid bin Fahd Al wada'ani, Ijtihad wa Taqlid 'inda Imam Syathibi, cet.I, (Dar At Tadmiyah, tth), h. 6 . dalam berfikir dan memahami sebuah nas. Hanya orang yang mempunyai bakat dan kemampuan untuk menggali hukum dari sumber aslinya.

Al-Qur'an dan hadis dalam sejumlah redaksi menyuruh umat manusia untuk menuntut ilmu termasuk menggali hukum dan hikmah yang terkandung di dalamnya. Namun bagi yang tidak mampu berijtihad, Allah Swt. perintahkan untuk bertanya kepada orang alim dan mengikutinya. Pendapat tersebut kemudian diartikan sebagai bermazhab. Karena mazhab dimaknai sebagai jalan pikiran seorang mujtahid dalam menemukan hukum dari sumber aslinya, yakni Al-Qur'an dan hadis, atau pendapat seorang mujtahid. Bermazhab berarti mengikuti pendapat ahli hukum Islam. Bermazhab juga dapat diartikan sebagai bertaklid kepada Imam mazhab atau ulama pengikut mazhab dalam bidang hukum. Bukan mengikuti langkah (metode) imam mujtahid bagaimana cara mereka mengistibat 
hukum-Islam dari sumber aslinya (al-Quran dan hadis) Bermazhab atau mengikuti mazhab sebagai alternatif bagi orang awan atau orang yang tidak mampu berijtihad.

\section{Mazhab}

Mazhab berasal dari kata dhahabayadhabu-dhahaban yang artinya jalan yang dilalui dan dilewati yang menjadi tujuan seseorang. $^{2}$ Ulama fikih berbeda dalam mendefinisikan mazhab secara istilah. Adapun definisi-definisi tersebut dapat dilihat sebagai berikut:

1. Wahbah Zuhaili memberi batasan mazhab sebagai segala hukum yang mengandung berbagai masalah, baik dilihat dari aspek metode yang mengantar pada kehidupan secara keseluruhan maupun aspek hukumnya sebagai pedoman hidup. ${ }^{3}$

2. Mazhab menurut Ibrahim al-Bajuri dan Muhammad Syata al-Dimyati adalah pendapat para Imam yang berkaitan dengan hukum. ${ }^{4}$

3. Muslim Ibrahim mendefinisikan mazhab sebagai hasil ijtihad seorang mujtahid tentang hukum dalam Islam yang digali dari ayat Al-Qur'an atau hadis yang dapat diijtihadkan. ${ }^{5}$

Dari beberapa pengertian di atas, dapat penulis simpulkan bahwa, yang dimaksud dengan mazhab menurut istilah meliputi dua pengertian. Pertama, mazhab adalah jalan pikiran atau metode yang ditempuh oleh seorang Imam mujtahid dalam menetapkan hukum atau peristiwa berdasarkan

${ }^{2}$ Luwis Ma'luf, Al-Munjid fi Al-Lughah wa Al-Alam, 1986, (Bayrut: Dar Al Masyariq), h. 239-240.

${ }^{3}$ Wahbah Al-Zuhayli, Al-Fiqh Al-Islami wa Adillatuhu juz 1, (Bayrut: Dar Al- Fikr.1989), h. 27

${ }^{4}$ Ibrahim al-Bajuri, Hasyiyah al Bajuri ala Abi Qasim al-Ghazi, Jilid I, (Semarang: Thaha Putra, t.th) h. 19 .

${ }^{5}$ Muslim Ibrahim, Pengantar Fiqh Maqaran, (Jakarta: Erlangga,1991) h. 47.
al-Quran dan hadis. Kedua, mazhab adalah fatwa atau pendapat seorang Imam mujtahid tentang hukum suatu peristiwa yang diambil dari Al-Qur'an dan hadis.

Istilah mazhab sering juga digunakan dalam banyak disiplin ilmu. Misalnya ilmu kalam. Ilmu tersebut dipelajari berbagai mazhab dan aliran, seperti Asy,,ariyah, Maturidiyah, Jabbariyah, Qadariyah, Syi'ah, Khawarij dan lainnya. Mazhab dapat juga diartikan sebagai aliran, kepercayaan atau sekte. Mazhab dipakai juga dalam permasalahan Tasawuf, Nahu, Saraf, dan Iainlain. Mazhab dalam kamus besar Indonesia sudah diindonesiakan yang artinya yaitu haluan, aliran mengenal hukum Islam. ${ }^{6}$

Banyak ulama memberikan definisi tenteng fiqh namun penulis menilai walaupun redaksinya berbeda, namun maksudnya sama. Maksud definisi tersebut yaitu, fikih merupakan pengetahuan atau pemahaman seorang mujtahid tentang hukum-hukum syara' yang digali dari sumber Al-Qur'an dan hadis. Pengertian mazhab fikih dalam pembahasan ini adalah aliran-aliran pemahaman hukum syara' dari seorang mujtahid yang diistinbat dari Al-Qur'an dan hadis. Dengan demikian dapat diartikan bermazhab fikih adalah mengikuti hasil ijtihad seseorang mujtahid tentang hukum sesuatu masalah atau mengikuti kaidah-kaidah istinbatnya.

\section{Taklid}

Kata taklid secara bahasa berasal dari kata qallada-yuqallidu-taqlidan, mengandung arti mengalungi, menghiasi, meniru, menyerahkan, dan mengikuti. Taklid juga dapat didefinisikan sebagai menerima pendapat orang lain dengan

${ }^{6}$ Depdikbud, Kamus Besar Indonesia, cet. III (Jakarta: Balai Pustaka, 2005) h. 726. 
tidak manpu mengemukakan alasannya. ${ }^{7}$ Seseorang yang bertaklid seolah-olah menggantungkan hukum yang diikutinya dari seorang mujtahid.

Sedangkan menurut istilah, taklid Ulama berbeda redaksi dalam mendefinisikan taqlid Definisi taqlid yang diambil oleh mayoritas ulama ushul fiqh, yaitu:

$$
\text { قَبَول قَوْل الغَيْرِ مِنْ غَيْرِ حُجَّةٍة }
$$

\section{"Menerima/mengikuti perkataan orang lain dengan tidak bersifat hujjah".}

Seperti orang awam mengikuti perkataan seorang mujtahid dalam beragama. Sedangkan jika perkataan yang diambil merupakan perkataan Rasulullah Saw. atau perkataan ulama yang telah menjadi ijma', maka ia bukanlah sebuah taqlid. Sebab perkataanperkataan tersebut merupakan hujjah. ${ }^{8}$

Ada juga ulama yang berpendapat bahwa taklid adalah:

$$
\text { الأخذ بقولِ الغَير معَ عدم مَعرفة الدليلهِ }
$$

"Mengambil perkataan/pendapat orang lain tanpa mengetahui dasar/dalil dari perkataan tersebut."

Definisi ini dinyatakan oleh beberapa ulama seperti imam Ibnu Qayyim Al Jauziyyah dan imam Asy Syaukani untuk menetapkan tingkatan ittiba' antara tingkatan ijtihad dan taqlid. Di mana mereka mengatakan bahwa ittiba' adalah mengambil pendapat orang lain sembari ia tahu dalil yang mendasari pendapat ini. ${ }^{9}$

${ }^{7}$ A. Hanafi, Pengantar Dan Sejarah Hukum Islam, (Jakarta: Bulan Bintang, 1984), h. 176. Lihat juga, Alaiddin Koto, Ilmu Fiqh dan Ushul Fiqh, (Jakarta: PT RajaGrafindo Persada, 2004), h.132.

${ }^{8}$ Abu Hamid Muhammad bin Muhammad alGhazali, Al-Mustasyfa, (Bayrut: Dar al Ihya' Turas Arabi, 1993), h. 389. Lihat juga Abu Hamid Muhammad Al-Ghazali, Al-Mankhul Fi Ta'liqati AlUsul, (Bayrut: Dar al-Fikri al Mu'asir, 1998), h. 582.

9 Ibnu Qayyim al-Jauziyah, I'lam AlMuwaqqi'in, Juz 4, (Bayrut: Dar al-Fikr, t.th), h. 192, 236.
Sedangkan menurut Nazar Bakry, taklid adalah mengikuti pendapat seseorang mujtahid atau ulama tertentu tanpa mengetahui sumber dan cara pengambilan pendapat tersebut. Taklid menurut istilah dapat juga dimaknai yaitu, menerima suatu ucapan orang lain serta memegang tentang suatu hukum agama dengan tidak mengetahui keteranganketerangan dan alasan-alasannya. Orang yang bertaklid disebut Muqallid. ${ }^{10}$

Berkaitan dengan taklid pada mazhabmazhab fikih yang sifat amaliyah adalah hal yang masih dipeselisihkan oleh para ulama. Perbedaan pandangan ulama dalam hal ini dapat dijelaskan berikut ini:

a. Bertaklid tidak dibolehkan dalam bentuk apapun, karena yang diwajibkan adalah berijtihad dan meneliti. Dengan demikian pada tiap orang mukallaf diwajibkan untuk berijtihad dengan kemampuan yang dimilikinya. Pendapat ini diungkapkan oleh Ibn Hazm dalam kitab al-Ihkam fi Usuli al-Ahkam, bertaklid haram dan tidak dibolehkan mengambil perkataaan orang lain tanpa dalil.

b. Berijtihad tidak dibolehkan setelah periode Imam-Imam mazhab dan harus bertaklid kepada mereka. Ini pendapat Hasywiyah.

c. Bertaklid tidak dibolehkan bagi orang mampu berijtihad dan bertaklid dibolehkan bagi orang yang tidak mampu berijtihad, pendapat ini adalah pendapat dianggap sahih oleh ulama-ulama mazhab.

Adapun dasar yang dijadikan dalil atas kebolehan taklid bagi orang awam yaitu, Firman Allah Ta'ala yang artinya:

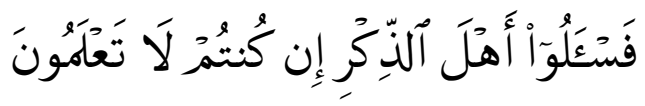

${ }^{10}$ Nazar Bakry, Fiqh dan Ushul Fiqh, cet. 4 (Jakarta: PT RajaGrafindo Persada, 2003), h. 61. 
"Maka bertanyalah kepada orang yang mempunyai pengetahuan jika kamu tidak mengetahui”. (QS Al-Nahl :43)

Ayat ini menunjukkan anjuran kepada orang yang tidak berilmu ataupun orang yang mampu berijtihad untuk bertanya kepada ahlu dzikr, yaitu orang yang memiliki ilmu pengetahuan. Dengan demikian dapat dikatakan bahwa, orang yang tidak mampu berijtihad, baik pada masa sahabat dan tabi'in menanyakan permasalahan hukum pada orang yang alim di kalangan mereka. Membebani seluruh manusia untuk berijtihad dapat menimbulkan kesulitan dan kesukaran. Dan ijtihad suatu kemampun dan bakat yang tidak dimiliki oleh semua orang, tetapi ulama tertentu. $^{11}$

Melihat fenomena yang ada pada manusia, maka hukum taklid terbagi kepada dua macam, yaitu taklid yang diperbolehkan dan taklid yang dilarang atau haram. Dengan demikian dapat penulis jelaskan bahwa, bertaklid dapat katagorikan menjadi dua:

1. Taklid yang diperbolehkan atau mubah, yaitu taklid bagi orang-orang yang belum sampai pada tingkatan sanggup mengkaji dalil dari hukum-hukum syari'at. Sebagaimana yang dikatakan Imam Hasan al-Banna, taklid adalah sesuatu yang mubah dan diperbolehkan oleh syari'at, namun meski demikian, hal itu tidak berlaku bagi semua manusia. Taklid hanya dibolehkan bagi setiap muslim yang belum sampai pada tingkatan Nazar atau tidak memiliki kemampuan untuk mengkaji dalil dari hukum-hukum syari'at, yaitu bagi orang yang tidak memiliki keahlian dalam mengkaji dalildalil hukum, atau kemampuan untuk

${ }^{11}$ Muhammad Ibrahim al Hafnawi, Tabsir an Nujaba' bi Haqi qati al ijtihad, wa al-Taqlid, al-Talfiq wa al- Ifta',(Cairo: Dar al Hadith, 1995), h. 207-212. menyimpulkan hukum dari Al-Quran dan hadis, serta tidak mengetahui ijma dan qiyas.

2. Taklid yang dilarang atau haram, yaitu bagi orang-orang yang sudah mencapai tingkatan nazar atau yang sanggup mengkaji hukum-hukum syari' at. ${ }^{12}$ Dalam persoalan ijtihad dan taklid ini, Syaukani mengomentari bahwa, ijtihad wajib atas orang yang memiliki kualifikasi mujtahid. Taklid dilarang bagi mereka karena berdasarkan Al-Quran surat an-Nisa' ayat 59, yaitu:

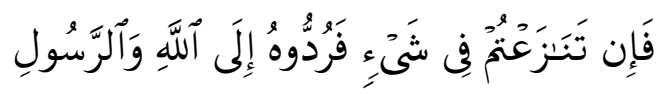

Kemudian jika kamu berlainan pendapat tentang sesuatu, maka kembalikanlah ia kepada Allah (AlQuran) dan Rasul (sunnahnya). (QS. An-Nisa': 59)

Ayat tersebut menurut Syaukani, Allah swt. tidak memerintahkan kembali kepada pendapat seseorang dalam masalah agama, tetapi diperintah kembali kepada Allah dan Rasul-Nya, yakni kepada Al-Qur'an dan sunnah.

Dengan demikian maka seseorang harus dapat memetik kandungan Al-Qur'an dan sunnah dengan cara melakukan istinbat. Akan tetapi jika suatu permasalahan tidak ditemukan di dalam Al-Qur'an dan sunnah, maka harus melakukan ijtihad bi al ra'yi. Pandangan asySyaukani ini dapat diterima oleh para pengikut mazhab yang empat. Namun persoalannya adalah bagaimana jika kasus ini terjadi pada orang awam, apakah mereka tetap melakukan ijtihad. Para pengikut Imam Mazhab yang empat dalam konteks ini mewajibkan bagi

12 Yahya Muhammad, Ijtihad wa al-Taqlid wa al-Ittiba' wa Al-Nazar, cet 1 (Bayrut: Muassasah Intisyar Al Arabi, 2000), h. 143. 
orang awam untuk bertaklid kepada salah seorang mujtahid. Menurut mereka, orang awam yang tidak memiliki pengetahuan tentang hukum Islam, tidak mungkin dapat melakukan ijtihad, dan jika mereka tetap diwajibkan melakukan ijtihad, maka akan terjadi kekacauan hukum dalam masyarakat atau dapat mengakibatkan terbengkalainya berbagai sektor kehidupan, karena setiap orang sibuk mempersiapkan diri untuk melakukan ijtihad. $^{13}$ Dengan demikian persoalan bermazhab atau bertaklid kepada Imam mazhab, hanya dibolehkan bagi orang awam yang belum mampu berijtihad, sedangkan bagi orang yang mampu berijtihad tidak dibenarkan bertaklid atau bermazhab.

\section{IJTIHAD}

Ijtihad secara bahasa berasal dari kata Jahada. Kata ini berarti kesanggupan (alWus'u), kekuatan (al-Taqah), dan berat (alMasyaqqah). ${ }^{14}$ Ijtihad dapat juga disebut sebagai sebuah usaha yang sungguh-sungguh, yang sebenarnya bisa dilaksanakan oleh siapa saja yang sudah berusaha mencari ilmu untuk memutuskan suatu perkara yang tidak dibahas dalam Al-Quran maupun hadis secara jelas. Panulis mengutip beberapa pengertian ijtihad secara terminologi yang disebutkan oleh pakar ushul fikih di antaranya.

1. Imam al Ghazali, mendefinisikan ijtihad: ${ }^{15}$

${ }^{13}$ Nasrun Rusli, Konsep Ijtihad Asy-Syaukani Relevansinya bagi Pembaruan Hukum Islam di Indonesia, (Jakarta: Logos Wacana Ilmu, 1997), h. 117

14 Muhammad Abu Bakar Razi, Mukhtar Sihah, (Cairo: Dar al Manar ,t,t), h. 62. Lihat juga Ahmad bin Muhammad bin Ali al-Faiyumi al-Muqri, Misbahul Munir, (Bayrut: Maktabah al Asriyah 1997), h. 72

15 Abu Hamid Muhammad al-Ghazali, Mustasfa (Bayrut: Dar al Ihya Turas Arabi, 1993), h. 350

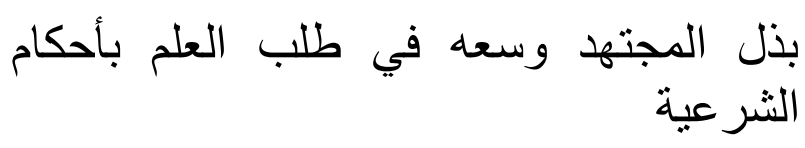

"Usaha sungguh-sungguh dari seorang mujtahid dalam rangka mengetahui hukumhukum syari 'at”.

2. Menurut Abu Zahrah ijtihad adalah: 168

بذل فقيه وسعة في استنباط الاحكام العملية من

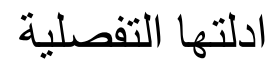

"Usaha seseorang ahli fikih dengan kemampuannya dalam mewujudkan hukum-hukum amaliah yang diambil dari dalil-dalil yang terperinci”.

Dari definisi yang dikemukakan para ulama di atas dapat dikatakan bahwa, ijtihad adalah suatu usaha dengan segenap kemampuan oleh seorang mujtahid untuk menggali hukum syara' dari sumber yang terperinci, yaitu Al-Qur'an dan hadist. Ijtihad juga dapat disebut sebagai proses penggalian hukum syariat dari dalil-dalil yang rinci yakni, Al-Qur'an, hadis, Ijma', Qiyas dan dalil lainnya.

Landasan diperbolehkan ijtihad adalah dalil dari Al-Qur'an dan hadis, baik melalui pernyataan yang jelas maupun berdasarkan isyarat, di antaranya yaitu :

1. Firman Allah swt. dalam surat an-Nisa' ayat 105 yang berbunyi yaitu:

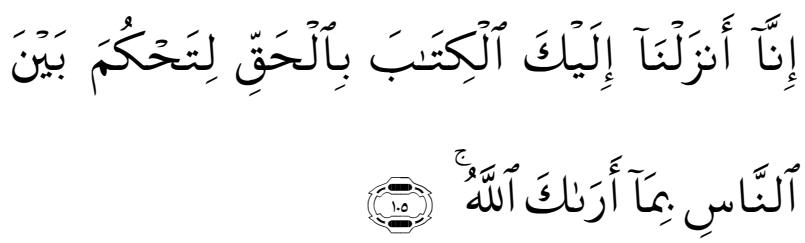

"Sesungguhnya Kami telah menurunkan kitab kepadamu dengan membawa kebenaran, supaya kamu mengadili antara manusia dengan apa yang telah Allah wahyukan kepadamu" (Q.S An Nisa: 105)

2. Sunnah. Di antaranya yaitu hadist Mu'az ibn Jabal ketika diutus ke Yaman. Yang artinya: "Dari Mu'az ibn Jabal ra bahwa 
Nabi saw ketika mengutusnya ke Yaman, Nabi bertanya: Bagaimana kamu jika dihadapkan permasalahan hukum? Ia berkata: Saya berhukum dengan kitab Allah. Nabi berkata: Jika tidak terdapat dalam kitab Allah? ia berkata: Saya berhukum dengan sunnah Rasulullahs. Nabi berkata: Jika tidak terdapat dalam sunnah Rasul Saw? ia berkata: Saya akan berijtihad dan tidak berlebih (dalam ijtihad). Maka Rasul Saw memukul ke dada Mu'az dan berkata: Segala puji bagi Allah yang telah sepakat dengan utusannya (Mu'az) dengan apa yang diridhai Rasulullah saw." 16

Hadis ini menunjukkan bahkan, berijtihad berlaku apabila sebuah persoalan tidak didapatkan sumbernya dari Al-Qur'an atau hadis. Ijtihad juga dipandang sebagai suatu tindakan terpuji, apapun hasilnya.

Menyingkapi dalil boleh ijtihad, baik ayat maupun hadis, menurut penulis kontek ayat membolehkan ijtihad secara isyarah ayat secara umum, sedangkan dalam hadis kebolehan ijtihad dibatasi pada Mu'az sebagai qadhi, atau mufti. Sedangkan hadis yang diriwayat imam Muslim khusus ijtihad seorang hakim. Dengan demikian dapat dipahami bahwa, ijtihad diharuskan pada seorang hakim, tidak berlaku ijtihad kepada untuk orang awam.

Para ulama telah merumuskan persyaratan seorang mujtahid dengan rumusan dan redaksi yang berbeda-beda. Namun dalam pembahasan ini akan dikemukakan syaratsyarat mujtahid yang dirumuskan oleh Wahbah Zuhaili sebagai berikut:

a. Mengetahui makna ayat hukum, baik secara bahasa maupun secara istilah. Menurut al-Ghazali, al-Razi Ibnu Arabi

16 Abu Dawud Sulaiman Muhammad bin Asy'as al-Sijistani, Sunan Abu Dawud, Juz II, (Indonesia: Maktabah Dahlān, t.t), h. 308. jumlah ayat hukum yang perlu dikuasai yaitu sekitar lima ratus ayat.

b. Mengetahui hadis-hadis hukum, baik secara bahasa maupun istilah. Menurut Ibnu Arabi (w.534 H) hadis ahkam berjumlah 3000 hadis, sedangkan menurut riwayat dari Ahmad bin Hanbal, hadis yang berkenaan dengan hadis hukum ada 1200 hadis. Tetapi Wahbah Zuhayli tidak sependapat, menurutnya yang terpenting mujtahid mengerti seluruh hadis-hadis hukum yang terdapat dalam kitab-kitab besar, seperti sahih Bukhari, sahih Muslim, dan lain-lain.

c. Mengetahui Al-Qur"an dan hadis yang telah dinasakh dan mengetahui ayat dan hadis yang menasakh. Tujuannya agar mujtahid tidak mengambil kesimpulan dari nas yang sudah tidak berlaku lagi.

d. Mengetahi sesuatu yang hukumnya telah dihukumi oleh ijma, sehingga tidak menetapkan hukum yang bertentangan dengan ijma.

e. Mengetahui qiyas dan sesuatu yang berhubungan dengan qiyas yang meliputi rukun, syarat, illat hukum dan cara istinbatnya dari nas.

f. Menguasai bahasa Arab tentang nahwu, saraf, ma'ani, bayan, dan uslub-nya, karena Al-Qur'an dan hadis berbahasa Arab. Oleh karena itu tidak mungkin dapat mengistinbatkan hukum yang berdasar dari keduanya tanpa mengetahui bahasa keduanya. Di antaranya mengetahui lafad umum dan khusus, hakikat dan majaz, mutlaq dan muqayyad, dan sebagainya. Semua ini tidak disyaratkan untuk dihafal, tetapi cukup memiliki kemampuan untuk memahami secara benar ungkapan-ungkapan dalam bahasa Arab dan kebiasaan orang Arab menggunakannya. g. Mengetahui ilmu ushul fikih, karena ushul fikih adalah tiang ijtihad, berupa dalil-dalil secara terperinci yang menunjukan hukum 
melalui cara tertentu dan semuanya ada dalam ilmu ushul fikih. Dan al-Razi dalam al-mahsul mengatakan bahwa, "Ilmu yang paling penting untuk dikuasai oleh mujtahid adalah ilmu ushul fiqh.'

h. Mengetahui maqasid syar'iyah dalam penetapan hukum, karena pemahaman nas dan penerapannya dalam peristiwa bergantung kepada maqasid syari'yah. Penunjukan suatu lafad kepada maknanya mengandung beberapa kemungkinan. Pengetahuan tentang maqasid memberi keterangan untuk memilih mana yang layak untuk difatwakan. Dan terpenting lagi pengetahuan tentang maqasid adalah prinsip hukum dalam Al-Qur'an dan sunah dapat dikembangkan seperti dengan qiyas, istihsan, dan maslahah mursalah. ${ }^{17}$

Sebahagian ulama menjabarkan persyaratan ijtihad dalam kitab fikih mencapai lima belas syarat. Persyaratan yang begitu selektif dan ketat dimaksudkan bahwa, seorang yang digolongkan dalam mujtahid benar memiliki ilmu dan intelektualnya benar-benar teruji dan masuk dalam istilah Badhlu wust $^{\prime}$ (mengerahkan kemampuan inteletualitas) Adapun dilihat persyaratan-persyaratan di atas tentu sulit menemukan orang yang memenuhi seluruhnya. Masing-masing orang tentu memiliki kelebihan dan kekurangan. Ada yang hanya memenuhi sebagian dan ada yang memenuhi lebih lengkap.

Oleh karena demikian ulama fikih menetapkan beberapa tingkatan mujtahid. Imam Nawawi dalam majmu' Syarh alMuhadhab menyatakan bahwa, mujtahid terbagi dua yaitu, mustaqil dan ghairu mustaqil.

Mujtahid mustaqil terbagi empat, yaitu:

1. Mujtahid mutlaq atau mustaqil (mandiri), yaitu ulama yang melakukan ijtihad dan

${ }^{17}$ Wahbah Zuhayli, Usul Fiqh al-Islami..., h. 1044-1049. merumuskan sendiri kaidah-kaidah penggalian hukumnya. Termasuk dalam tingkatan ini adalah keempat Imam Mazhab, yaitu Abu Hanifah (80-150 H), Imam Malik bin Anas (93-179 H), Imam Syafi"i (150-2104 H) dan Imam Ahmad bin Hanbal (164-241 H).

2. Mujtahid Mutlaq Muntasib, yaitu ulama yang mengikuti metode Imam panutannya dalam menggali hukum berbagai bidang. Misalnya al-Muzani, al-Buwaiti, Za'farani di lingkungan mazhab Syafi'i dan Muhammad bin Hasan dan Abu Yusuf di lingkungan mazhab Hanafi. Mereka juga disebut sebagai mujtahid mutlaq.

3. Mujtahid muqayyad atau mujtahid takhrij, yaitu para ulama yang menggali hukum pada kasus-kasus yang belum diuraikan oleh Imam panutannya. Misalnya al-Karkhi, al-Sarkhasi, alazdawi, Abu Ishaq Asy Syirazi dan alMaruzi, dan lain sebagainya.

4. Mujtahid murajjih, yaitu ulama yang memilah-milah pendapat suatu mazhab dengan mengambil mana yang paling unggul dan sesuai dengan tuntutan kemaslahatan umat. Misalnya al-Rafi'i dan an-Nawawi di lingkungan mazhab Syafi'i.

5. Mujtahid fatwa yaitu ulama yang hafal dan paham terhadap kaidah-kaidah Imam mazhab, mampu menguasai persoalan yang sudah jelas maupun yang sulit, namun masih lemah dalam menetapkan suatu putusan berdasarkan dalil serta lemah dalam menetapkan qiyas. $^{18}$

18 Abu Zakarya Mahyiddin bin Syaraf alNawawi, Majmu'Syarh Al- Muhadhab, Jilid, I (Mekah: Maktabah al-Irsyad, t,t), h. 75-77 . Lihat juga Wahbah Zuhayli, Al Fiqh al Islami...,h. 1107-1109. 
Sementara itu Ibnu Qayyim al-Jauzi membagikan tingkatan mujtahid kepada empat tingkatan. ${ }^{19}$

1. Orang yang alim dengan Al-Qur'an dan hadis, dan pendapat sahabat. Ulama tersebut dikatagorikan kepada mujtahid.

2) Mujtahid muqayyad dengan mazhabmazhab yang diikutinya, yaitu orang yang mengerti fatwa mazhabnya, sumber pengambilannya dan ushulnya.

3) Mujtahid dalam mazhab adalah seseorang yang menisbahkan kepada mazhab, mampu menetapkan dalil, tetapi melampaui pandapat mazhabnya dan fatwa dan tidak menyalahinya.

4) Golongan yang memahami mazhab yang diikutinya, menguasai fatwa dan furu'nya. Mereka menetapkan diri dalam kelompok taklid dalam berbagai hal. Apabila disebut ayat Al-Qur'an atau hadis hanya semata-mata mengambil fadilah bukan sebagai dalil. Bahkan apabila ada fatwa sahabat, seperti fatwa Abu Bakar, Umar, Usman dan Ali yang berlawanan dengan Imam mereka, mereka mengabaikan fatwa sahabat dan mengamalkan dengan pendapat Imamnya.

Pengelompokan di atas, baik yang dikemukan Wahbah Zuhayli, ibn Qayyim atau ulama lain adalah bagian dari klarifikasi kemampuan manusia dalam memahami, meneliti, dan mengalisis terhadap dalil-dali fikih atau memahami dalil dari mazhab yang diikutinya. Disebabkan perbedaan kemampuan manusia dalam penalaran, maka para ulama fikih maupun ushul fikih mengkatagorikan mujtahid dalam beberapa tingkatan tertentu.

\section{Dampak Mazhab terhadap Perkembangan Fiqih}

\footnotetext{
${ }^{19}$ Ibnu Qayyim al-Jauzi, 'Ilam al-Muwaqi 'in
} Jilid, 4 h. 212.
Lahirnya mazhab fikih pada abad ke II dan ke III merupakan puncak kejayaaan proses hukum di dunia Islam. Berakhirnya kejayaan mazhab yaitu dimulai dari kewafatan tokoh mazhab yang terakhir. Dalam hal ini Ibn Jarir al-Tabari (310) sampai kewafatan tiga tokoh pemikir orisinal (mujtahid) yang terakhir Ibnu Taimiyah $728 \mathrm{H} / 1328 \mathrm{M}$, as-Syatibi $790 \mathrm{H}$ /1388 M dan Ibnu Khaldun 808 H /1406 M.

Pada era pasca terbentuknya mazhabmazhab, gejala fanatisme dan membela mazhabnya masing-masing sudah menjalar di kalangan umat khususnya para ulamanya, berangsur-angsur fikih mengalami stagnasi dan kejumudan. Kebebasan berpendapat mengalami pembatasan-pembatasan, pintu ijtihad dinyatakan telah tertutup, sehingga daya kritis ulama mengalami penurunan drastis. Mereka merasa cukup dan mencukupkan diri dengan mazhab sudah ada. Gejala taklid dan fanatisme mazhab menjadi pemandangan umum hampir di seluruh negerinegeri muslim. Pendapat dan fatwa dari ulama mazhab mereka terdahulu dianggap sudah final dan harus diikuti tanpa boleh mengajukan kritikan apalagi koreksi. ${ }^{20}$

Pengaruh tersebut dirasakan setelah dinasti Abbasiyah berakhir, kekuasaan Islam mulai lemah, perhatian penguasa kepada fuqaha dan fikih sudah berkurang, dukungan nyata pada perkembangan fikih Islam tidak maksimal lagi. Ulama-ulama merasa puas dengan mazhab yang telah ada. Proses ijtihad juga terhenti, akibatnya mereka berusaha untuk mengabadikan mazhab yang mereka anut dan mereka yakini kebenarannya. Mereka memperluas uraian pendapat Imam dengan menyusun kitab-kitab dalam mazhab yang mereka anut, sehingga usaha mereka hanya

20 Rasyad Hasan Khalil, Madkhal li Fiqh Islami : Tarikh Tasyri' Adwaru Tatawuruhu, Masadiruhu madhahib al- fiqhiyah (Cairo : Ikhwah Asyqiya'i. 1994), h. 156. 
membatasi kajian dalil yang disebutkan oleh Imam mereka, tanpa berani keluar atau menyalahinya. Pada sisi lain muncul anggapan bahwa, fikih sudah mapan, sehingga tidak memerlukan lagi usaha ijtihad, dengan demikian ruh kebangkitan Islam secara umum menurun.

Usaha ulama menurut Ali as-Sayis setelah lahirnya mazhab yaitu:

a. Menerima dari imam mereka berbagai hukum terhadap masalah-masalah yang telah diperkirakan sebelum kejadian terjadi. $^{21}$

b. Mengkaji pendapat-pendapat yang bertentangan dengan mazhab melalui tarjih, yakni mempertimbangkan dalil yang lebih kuat. ${ }^{22}$

c. Mendukung dan memperkuat mazhab yang dianut. Wujud dari dukungan antara lain, memperbanyak karya biografi para imam mazhab, membuat karya perbandingan mazhab, dan menetapkan mazhabnya yang paling benar, mengadakan perdebatan publik demi mengalahkan lawan mazhabnya. ${ }^{23}$

Kemudian pengaruh mazhab terhadap format fiqih secara spesifik dapat dilihat dari sisi pengertian fiqih yang memiliki pengertian, mengetahui hukum-hukum syara' yang bersifat praktis dari dalil-dalilnya yang terperinci.

Perkembangan fiqih tidak saja membahas persoalan aktual, tetapi juga menjawab persoalan yang akan terjadi atau bersifat antisipatif, sehingga bermunculan fiqih yang berdasarkan pengandaian tentang persoalan yang akan terjadi. Dengan demikian pendekatan yang dilakukan dalam fiqih tidak lagi pendekatan aktual pada masa tersebut, tetapi mulai bergeser pada pendekatan teoritis.

\section{Penutup}

Munculnya mazhab-mazhab pada masa tabi'-tabi'n tidak dapat dilepaskan dari dinamika dan perkembangan sejarah Islam setelah Rasulullah saw wafat. Para tabi'-tabi'n menghadapi berbagai realitas baru yang tidak ditemui sebelumnya. Hal ini disebabkan karena semakin luas wilayah kekuasaan Islam. Pergaulan umat Islam dengan bangsa-bangsa lain yang ditaklukkannya, terutama yang berkaitan dengan adat-istiadat dan tradisi bangsa tersebut, memaksa para Gubernur, hakim dan para ulama melakukan ijtihad untuk menjawab masalah-masalah baru yang belum pernah ditemui sebelumnya.

Pada sisi lain, kedudukan mazhab, dapat dilihat dari segi munculnya mazhab juga disebabkan adanya perbedaan-perbedaan yang muncul pada masa sahabat dalam memahami nas, baik Al-Qur'an atau hadis. Demikian juga mazhab muncul karena semakin luasnya wilayah kekuasaan Islam, sehingga hukum Islam menghadapi berbagai macam persoalan dalam masyarakat yang berbeda-beda tradisinya. Mazhab juga muncul karena munculnya ulama-ulama besar pendiri mazhab-mazhab fiqih yang berusaha menyebarkan pemahamannya dengan mendirikan pusat-pusat study tentang fiqih. Begitu juga karena adanya kecenderungan masyarakat Islam ketika memilih salah satu pendapat dari ulama-ulama mazhab pada saat menghadapi masalah hukum.

\footnotetext{
${ }^{21}$ Ibid., h. 157.

22 Muhammad Ali as-Sayis, Sejarah Fikih
} Islam, terj. Nurhadi ( Jakarta: al-kausar, 2003 ), h. $167-$ 168.

\footnotetext{
${ }^{23}$ Ibid., h. 170 .
} 



\section{DAFTAR PUSTAKA}

A. Hanafi, Pengantar Dan Sejarah Hukum Islam, Jakarta: Bulan Bintang, 1984.

Abu Hamid Muhammad al-Ghazali, Mustasfa, Bayrut: Dar al Ihya Turas Arabi, 1993.

Abu Dawud Sulaiman Muhammad bin Asy'as al-Sijistani, Sunan Abu Dawud, Juz II, Indonesia: Maktabah Dahlān, t.t.

Abu Hamid Muhammad Al-Ghazali, AlMankhul Fi Ta'liqati Al-Usul, Bayrut: Dar al-Fikri al Mu'asir, 1998.

Abu Zakarya Mahyiddin bin Syaraf alNawawi, Majmu'Syarh Al- Muhadhab, Jilid, I, Mekah: Maktabah al-Irsyad, t,t.

Ahmad bin Muhammad bin Ali al-Faiyumi alMuqri, Misbahul Munir, Bayrut: Maktabah al Asriyah 1997.

Alaiddin Koto, Ilmu Fiqh dan Ushul Fiqh, Jakarta: PT RajaGrafindo Persada, 2004.

Depdikbud, Kamus Besar Indonesia, cet. III Jakarta: Balai Pustaka, 2005.

Ibrahim al-Bajuri, Hasyiyah al Bajuri ala $A b$ i Qasim al-Ghazi, Jilid I, Semarang: Thaha Putra, t.th.

Ibnu Qayyim al-Jauziyah, I'lam $A l$ Muwaqqi'in, Juz 4, Bayrut: Dar al-Fikr, t.th.

Luwis Ma'luf, Al-Munjid fi Al-Lughah wa AlAlam, 1986, Bayrut: Dar Al Masyariq.

Rasyad Hasan Khalil, Madkhal li Fiqh Islami : Tarikh Tasyri' Adwaru Tatawuruhu, Masadiruhu madhahib al-fiqhiyah, Cairo : Ikhwah Asyqiyai, 1994.
Muslim Ibrahim, Pengantar Fiqh Maqaran, Jakarta: Erlangga, 1991.

Muhammad Ibrahim al Hafnawi, Tabsir an Nujaba' bi Haqi qati al ijtihad, wa alTaqlid, al-Talfiq wa al-Ifta',Cairo: Dar al Hadith, 1995.

Muhammad Abu Bakar Razi, Mukhtar Sihah, Cairo: Dar al Manar ,t,t.

Muhammad Ali as-Sayis, Sejarah Fikih Islam, terj. Nurhadi, Jakarta: al-kausar, 2003.

Nazar Bakry, Figh dan Ushul Fiqh, cet. 4 Jakarta: PT RajaGrafindo Persada, 2003.

Nasrun Rusli, Konsep Ijtihad Asy-Syaukani Relevansinya bagi Pembaruan Hukum Islam di Indonesia, Jakarta: Logos Wacana Ilmu, 1997.

Yahya Muhammad, Ijtihad wa al-Taqlid wa al-Ittiba' wa Al-Nazar, cet 1, Bayrut: Muassasah Intisyar Al Arabi, 2000.

Wahbah Al-Zuhayli, Al-Fiqh Al-Islami wa Adillatuhu juz 1, Bayrut: Dar AlFikr.1989.

Walid bin Fahd Al wada'ani, Ijtihad wa Taqlid 'inda Imam Syathibi, cet.I, Dar At Tadmiyah, tth. 